\title{
The effects of different amounts and types of fat on metabolites in the rumen of sheep ${ }^{*}$
}

\author{
M. Szumacher-Strabel ${ }^{1}$, A. Potkański ${ }^{1}$, A. Cieślak' ${ }^{1}$, \\ J. Kowalczyk ${ }^{2}$ and M. Czauderna ${ }^{2}$ \\ 'Department of Animal Nutrition and Feed Management, \\ August Cieszkowski Agricultural University \\ Wolynska 33, 60-637 Poznań, Poland \\ 2 The Kielanowski Institute of Animal Physiology and Nutrition, \\ Polish Acadeny of Sciences \\ 05-11-Jablonna, Poland
}

\section{ABSTRACT}

The experiments were carried out in a $4 \times 4$ Latin square design on 4 rams ( $40 \pm 5 \mathrm{~kg}$ ) fitted with permanent rumen cannulas to determine the effects of fat source on basic rumen parameters. The basic ration for the control group consisted of meadow hay and concentrate (60:40) and was supplemented for experimental groups with rape seed oil, hydrogenated rape seed oil, or linseed oil at a level of 0 (control), 4,8 and $10 \%$ in dry matter of concentrate. Samples of rumen fluid were analyzed for ammonia, volatile fatty acid (VFA) concentrations, and pH. VFA profiles, except of the level of isovaleric acid, were not influenced by the type of fat when rape seed oil or hydrogenated rape seed oil was added to sheep rations $(\mathrm{P}<0.05 ; \mathrm{P}<0.01)$. A significant $(\mathrm{P}<0.05 ; \mathrm{P}<0.01)$ decrease in the ammonia level was found when 4,8 and $10 \%$ of rape seed oil was supplied to the ration. The addition of rape seed oil caused an increase $(\mathrm{P}<0.01)$ in $\mathrm{pH}$ in the group with $10 \%$ fat supplementation. Hydrogenated rape seed oil and linseed oit have no influence on the rumen pll level. Diets for ruminants can be supplemented with up to $10 \%$ of vegetable origin fat as an additional energy source without altering ruminal fermentation when the proper forage: concentrate ratio is maintained.

KEY WORDS: sheep, fat, volatile fatty acids, ammonia, $\mathrm{pH}$

* Supported by the State Committee for Scientilic Research, Grant No. 5 PO6E 02516 


\section{INTRODUCTION}

Accurate estimates of energy and protein values of diets is important because of the large quantities of these nutrients required by high producing ruminants. Diets that do not provide adequate energy and protein reduce milk production, cause excessive weight loss, impair reproduction and may decrease resistance to disease (Weiss, 1998). Rumen microorganisms break down plant material to provide the energy and protein required for their growth and during this process, they produce volatile fatty acids (VFAs) and ammonia as waste products (Garnsworthy, 1997). Fat supplements in ruminant rations can have a deleterious effect on these basic rumen parameters, as well as on rumen $\mathrm{pH}$. The response by ruminants to supplementary fat is complex and not always predictable.

The aim of the experiment was to determine the effect of different kinds of vegetable origin fat added as an additional energy source on the levels of basic metabolites such as VFA and ammonia, and on $\mathrm{pH}$ in the rumen fluid.

\section{MATERIAL AND METHODS}

\section{Animals and diets}

The experiments were carried out in a $4 \times 4$ Latin square design on 4 rams $(40 \pm 5 \mathrm{~kg})$ fitted with permanent rumen cannulas to determine the effects of fat source on basic rumen parameters. The basic ration for the control group consisted of meadow hay and concentrate (60:40), which was supplemented for the experimental groups with rape seed oil, hydrogenated rape seed oil, or linseed oil at a level of 0 (control), 4, 8 and $10 \%$ in dry matter of the diet.

The energy value of the rations was $5.06 \mathrm{MJ} \mathrm{EN} / \mathrm{kg}$, whereas the crude protein content was $118 \mathrm{~g} / \mathrm{kg}$. The daily ration was divided into two equal portions and fed at 08.00 and $18.00 \mathrm{~h}$. Water was continuously available.

\section{Sampling and analysis}

The experiments consisted of four 16-day trials, 14 days for adaptation to the diet, the last two for sample collection. Samples of the rumen fluid were collected before the morning feeding and 3 and $6 \mathrm{~h}$ after feeding (Grummer et al., 1993). $\mathrm{pH}$ was measured potentiometrically, ammonia according to Conway (1962), and individual volatile fatty acids by gas chromatography as described by Ziołecki and Kwiatkowska (1973).

Statistical analysis

All data were analyzed using SAS procedures (User's Guide, 1990). 


\section{RESULTS}

The ruminal VFA profiles observed in the experiments did not indicate modification except for the level of isovaleric acid when rape seed oil (Table 1) and hydrogenated rape seed oil (Table 2) were added to the sheep ration. A slight but significant $(\mathrm{P}<0.05)$ decrease in the level of isovaleric acid was observed when $8 \%$ of hydrogenated rape seed oil was added, and a significant $(\mathrm{P}<0.05)$ increase was seen when $10 \%$ hydrogenated rape seed oil was added. A significant decrease $(\mathrm{P}<0.05 ; \mathrm{P}<0.01)$ in the level of isovaleric acid in all experimental groups was recorded when 4,8 and $10 \%$ of rape seed oil was added. No changes were observed in other groups, regardless of the source and level of fat added. The concentrations of VFAs when linseed oil was added are presented in Table 3 . The ammonia level decreased significantly $(\mathrm{P}<0.05 ; \mathrm{P}<0.01)$ (Table 4$)$ when 4,8 and $10 \%$ of rape seed oil was added to rations. Similar trends were observed when hydroge-

TABLE 1

Effect of rape seed oil on concentration of individual VFA in the rumen of sheep, $\mathrm{mmol} / \mathrm{L}$

\begin{tabular}{|c|c|c|c|c|c|c|c|c|}
\hline \multirow{2}{*}{ Rape seed oil,\% } & \multicolumn{2}{|c|}{0} & \multicolumn{2}{|c|}{4} & \multicolumn{2}{|c|}{8} & \multicolumn{2}{|c|}{10} \\
\hline & mean & $\mathrm{CV}$ & mean & $\mathrm{CV}$ & mean & $\mathrm{CV}$ & mean & $\mathrm{CV}$ \\
\hline Acetic acid & 85.18 & 27.83 & 72.02 & 28.11 & 74.10 & 30.86 & 67.11 & 26.62 \\
\hline Propionic acid & 20.91 & 28.04 & 22.19 & 34.07 & 21.52 & 36.10 & 22.06 & 32.70 \\
\hline Butyric acid & 11.54 & 40.87 & 12.04 & 24.58 & 12.75 & 30.90 & 10.06 & 31.98 \\
\hline Isobutyric acid & 1.67 & 19.18 & 1.55 & 26.33 & 1.66 & 24.61 & 1.41 & 18.45 \\
\hline Valeric acid & 2.12 & 54.57 & 1.86 & 58.75 & 1.83 & 57.80 & 1.77 & 56.86 \\
\hline Isovaleric acid & $2.90^{\mathrm{ABa}}$ & 19.90 & $1.54^{B C}$ & 35.90 & $1.78^{\mathrm{Cab}}$ & 33.26 & $1.35^{\mathrm{Ab}}$ & 24.00 \\
\hline
\end{tabular}

means in rows with the same letter differ statistically significant ${ }^{A, B, C}-P<0.01 ;{ }^{a, b, c}-P<0.05$

TABLE 2

Effect of hydrogenated rape seed oil on concentration of individual VFA in the rumen of sheep, $\mathrm{mmol} / \mathrm{L}$

\begin{tabular}{|c|c|c|c|c|c|c|c|c|}
\hline \multirow{2}{*}{$\begin{array}{l}\text { Hydrogenated } \\
\text { rape seed oil,\% }\end{array}$} & \multicolumn{2}{|c|}{0} & \multicolumn{2}{|c|}{4} & \multicolumn{2}{|c|}{8} & \multicolumn{2}{|c|}{10} \\
\hline & mean & $\mathrm{CV}$ & mean & $\mathrm{CV}$ & mean & $\mathrm{CV}$ & mean & $\mathrm{CV}$ \\
\hline Acetic acid & 72.86 & 19.41 & 68.38 & 23.91 & 68.25 & 21.02 & 65.37 & 20.59 \\
\hline Propionic acid & 19.99 & 27.20 & 21.80 & 30.62 & 20.29 & 28.03 & 23.69 & 44.13 \\
\hline Butyric acid & 13.13 & 19.67 & 10.02 & 27.59 & 11.35 & 39.48 & 10.19 & 27.66 \\
\hline Isobutyric acid & 1.57 & 13.84 & 1.56 & 22.07 & 1.43 & 22.25 & 1.57 & 13.75 \\
\hline Valeric acid & 1.85 & 49.40 & 1.83 & 47.03 & 1.58 & 42.87 & 1.79 & 55.55 \\
\hline Isovaleric acid & 1.45 & 16.78 & 1.48 & 36.80 & $1.17^{\mathrm{a}}$ & 32.46 & $1.61^{\mathrm{a}}$ & 39.52 \\
\hline
\end{tabular}

means in rows with the same letter differ statistically significant ${ }^{\mathrm{A}, \mathrm{B}, \mathrm{C}}-\mathrm{P}<0.01 ;{ }^{\mathrm{a}, \mathrm{b}, \mathrm{c}}-\mathrm{P}<0.05$ 
Effect of linseed oil on concentration of individual VFA in the rumen of sheep, $\mathrm{mmol} / \mathrm{L}$

\begin{tabular}{|c|c|c|c|c|c|c|c|c|}
\hline \multirow{2}{*}{ Linseed oil,\% } & \multicolumn{2}{|c|}{0} & \multicolumn{2}{|c|}{4} & \multicolumn{2}{|c|}{8} & \multicolumn{2}{|c|}{10} \\
\hline & mean & $\mathrm{CV}$ & mean & $\mathrm{CV}$ & mean & $\mathrm{CV}$ & mean & $\mathrm{CV}$ \\
\hline Acetic acid & 66.30 & 28.39 & 65.93 & 16.38 & 59.09 & 28.14 & 59.01 & 21.94 \\
\hline Propionic acid & 18.11 & 31.60 & 20.95 & 26.20 & 16.64 & 29.42 & 21.36 & 39.88 \\
\hline Butyric acid & 13.51 & 47.92 & 13.16 & 19.51 & 10.03 & 31.82 & 9.64 & 17.53 \\
\hline Isobutyric acid & 1.49 & 29.48 & 1.57 & 21.27 & 1.29 & 18.80 & 1.35 & 16.94 \\
\hline Valeric acid & 1.86 & 58.13 & 1.65 & 33.81 & 1.50 & 55.13 & 1.59 & 44.61 \\
\hline Isovaleric acid & 1.48 & 23.39 & 1.51 & 17.56 & 1.19 & 19.10 & 1.43 & 23.00 \\
\hline
\end{tabular}

means in rows with the same letter differ statistically significant ${ }^{\mathrm{A}, \mathrm{B}, \mathrm{C}}-\mathrm{P}<0.01 ;{ }^{\mathrm{a}, \mathrm{b}, \mathrm{c}}-\mathrm{P}<0.05$

TABLE 4

Concentration of rumen ammonia in sheep fed diets with different source of fat supplementation, $\mathrm{mmol} / \mathrm{L}$

\begin{tabular}{|c|c|c|c|c|c|c|c|c|}
\hline \multirow{2}{*}{$\begin{array}{l}\text { Supplemented } \\
\text { oil, } \%\end{array}$} & \multicolumn{2}{|c|}{0} & \multicolumn{2}{|c|}{4} & \multicolumn{2}{|c|}{8} & \multicolumn{2}{|c|}{10} \\
\hline & mean & $\mathrm{CV}$ & mean & $\mathrm{CV}$ & mean & $\mathrm{CV}$ & mean & $\mathrm{CV}$ \\
\hline Rape seed oil & $7.67^{A B}$ & 37.78 & $6.18^{a}$ & 36.85 & $5.42^{\mathrm{B}}$ & 43.32 & $6.11^{\mathrm{Aa}}$ & 9.05 \\
\hline $\begin{array}{l}\text { Hydrogenated } \\
\text { rape seed oil }\end{array}$ & 4.05 & 52.41 & 3.97 & 57.91 & 3.61 & 55.33 & 2.32 & 60.35 \\
\hline Linseed oil & 3.23 & 66.45 & 3.10 & 52.79 & 2.58 & 63.72 & 3.25 & 67.96 \\
\hline
\end{tabular}

means in rows with the same letter differ statistically significant ${ }^{A, B .}, \mathrm{P}-0.01$; ${ }^{\text {a.b.c. }}-\mathrm{P}<0.05$

nated rape seed oil and linseed oil were added, but the differences were not significant. The addition of rape seed oil caused an increase $(\mathrm{P}<0.01)$ in the $\mathrm{pH}$ (Table 5) in the group receiving $10 \%$ fat supplementation. Hydrogenated rape seed oil and linseed oil had no influence on rumen $\mathrm{pH}$.

TABLE 5

Mean rumen $\mathrm{pH}$ in sheep fed diets with different source of fat supplementation

\begin{tabular}{|c|c|c|c|c|c|c|c|c|}
\hline \multirow{2}{*}{$\mathrm{pH}$} & \multicolumn{2}{|c|}{0} & \multicolumn{2}{|c|}{4} & \multicolumn{2}{|c|}{8} & \multicolumn{2}{|c|}{10} \\
\hline & mean & $\mathrm{CV}$ & mean & $\mathrm{CV}$ & mean & $\mathrm{CV}$ & mean & $\mathrm{CV}$ \\
\hline Rape seed oil & $6.88^{\mathrm{c}}$ & 5.09 & $6.75^{\wedge}$ & 7.56 & $6.72^{\mathrm{B}}$ & 11.74 & $8.06^{\mathrm{ABC}}$ & 2.43 \\
\hline $\begin{array}{l}\text { Hydrogenated } \\
\text { rape seed oil }\end{array}$ & 6.28 & 5.20 & 7.18 & 13.07 & 6.36 & 10.58 & 6.96 & 6.51 \\
\hline Linseed oil & 6.80 & 15.05 & 6.66 & 5.14 & 6.62 & 9.39 & 6.70 & 11.67 \\
\hline
\end{tabular}

means in rows with the same letter differ statistically significant ${ }^{\mathrm{A} B \mathrm{~B} . \mathrm{C}}-\mathrm{P}<0.01 ;{ }^{\mathrm{a}, \mathrm{b}, \mathrm{c}}-\mathrm{P}<0.05$ 


\section{DISCUSSION}

Volatile fatty acids are produced in the rumen by microbial fermentation of carbohydrates and protein. The concentration of acetic, propionic and butyric acids and their proportions are related to the level of feed intake (Sutton, 1985) and the composition of the diet (Murphy et al., 1982). High forage diets deliver substrates for microorganisms and do not alter fermentation in the rumen. There is considerable interest in modification of rumen fermentation towards increasing the efficiency of production of ruminant animal products (Hobson and Stewart, 1997). Possible ways of altering rumen fermentation include modification of the diet and use of feed additives. Fat added to ruminant rations as an additional source of energy can alter rumen fermentation by inhibiting species of microorganisms that are prominent in cellulose degradation, and thus production of the main VFAs and ammonia. In the presented experiment, diets supplemented with fat had no effect on the level of these fatty acids. Neither composition of the diet, nor addition of fat influences VFA levels. According to Jenkins (1993) fat that normally inhibits fermentation and digestion often causes less inhibition when the hay content of the basal diet is high. Similar observations have been made by Tackett et al. (1996) who fed cows high forage diets with $10 \%$ added rape seed oil.

Most efforts are aimed at increasing the ability of rumen microorganisms to assimilate ammonia, thus reducing nitrogen loss to the animal (Hobson and Stewart, 1997). The level of ammonia, the major source of nitrogen for bacteria in the rumen, was affected only by adding rape seed oil, but in all groups the ammonia level was sufficient for maximal microbial growth yield. Addition of fat supplements had no influence on rumen $\mathrm{pH}$. It is important to maintain the proper $\mathrm{pH}$ because some rumen microorganisms, such as cellulolytic bacteria, fail to grow at low $\mathrm{pH}(<6.0)$, which leads to a decrease in dry matter intake, fibre digestibility and microbial yield, and increased feed costs. Boila et al. (1993) and Madison Anderson et al. (1997) also did not observe rumen disturbances in experiments on adding fat to ruminant diets. When the proper forage:concentrate ratio is maintained, diets for ruminants can be supplemented with up to $10 \%$ vegetable origin fat as an additional energy source without altering fermentation in the rumen.

\section{REFERENCES}

Boila R.J., Macinnis Mabon B., Ingalls J.R., 1993. Response of dairy cows to barley grain, tallow or whole sunflower seed as supplemental energy in carly lactation. Can. J. Anim. Sci. 73, 327-342 Conway E.J., 1962. Microdiffusion Analysis and Volumetric Error. Crosby Lockwood, London Garnsworthy P.C., 1997. Fats in dairy cow diet. In: P.C. Garnsworthy, J. Wiseman (Editors). Recent Advances in Animal Nutrition. Nottingham University Press, pp. 87-104 
Grummer R.R., Melissa L.L., Barmore J.A., 1993. Rumen fermentation and lactation performance of cows fed roasted soybeans and tallow. J. Dairy Sci. 76, 2674-2681

Hobson P.N., Stewart C.S., 1997. The Rumen Microbial Ecosystem. Chapman and Hall, St. Edmundsbury Press, Suffolk

Jenkins T.C., 1993. Symposium: Advances in ruminant lipid metabolism. Lipid metabolism in the rumen. J. Dairy Sci. 76, 3851-3863

Madison-Anderson R.J., Schingoethe D.J., Brouk M.J., Baer R.J., Lentsch M.R., 1997. Response of lactating cows to supplemental unsaturated fat and niacin. J. Dairy Sci. 80, 1329-1338

Murphy M.R., Baldwin R.L., Koong L., 1982. Estimation of stoichiometric parameters for rumen fermentation of roughage and concentrate diets. J. Anim. Sci. 55, 411-421

SAS $^{\star}, 1990$. SAS/STAT Users Guide (Release 6.03). SAS Institute Inc., Cary, NC (USA)

Sutton J.D., 1985. Digestion and absorption of energy substrates in the lactating cow. J. Dairy Sci. 68, 3376-3393

Tackett V.L., Bertrand J.A., Jenkins T.C., Pardue F.E., Grimes L.W., 1996. Interaction of dietary fat and acid detergent fiber diets of lactating dairy cows. J. Dairy Sci. 79, 270-275

Weiss W.P., 1998. Estimating the available energy content of feeds for dairy cattle. J. Dairy Sci. 81, 830-839

Ziołecki A., Kwiatkowska E., 1973. Gas chromatography of $\mathrm{C}_{1}$ to $\mathrm{C}_{5}$ fatty acids in rumen and fermentation media. J. Chromatogr. 80, 250-254

\section{STRESZCZENIE}

\section{Wplyw rodzaju i ilości dodanego do diety tluszczu na niektóre metabolity w żwaczu owiec}

Doświadczenie, którego celem było zbadanie wpływu rodzaju i ilości dodanego tłuszczu do diety składającej się z siana i mieszanki treściwej $(60: 40 \%)$ na zmiany stężenia niektórych metabolitów w żwaczu, przeprowadzono na 4 trykach z trwałymi kaniulami żwaczowymi, w układzie kwadratu łacińskiego $4 \times 4$. Do dawki podstawowej dodawano tłuszcze pochodzenia roślinnego - olej rzepakowy, uwodorniony olej rzepakowy lub olej lniany w ilości 0 (grupa kontrolna), 4, 8 i 10\% suchej masy paszy treściwej. Określono poziom lotnych kwasów thuszczowych, amoniaku oraz pH płynu żwaczowego. Stwierdzono statystycznie istotne różnice $(\mathrm{P}<0,05 ; \mathrm{P}<0,01)$ w poziomie kwasu izowalerianowego u owiec otrzymujących dodatek oleju rzepakowego oraz uwodornionego oleju rzepakowego. Stwierdzono również statystycznie istotny $(\mathrm{P}<0,05 ; \mathrm{P}<0,01)$ spadek poziomu amoniaku we wszystkich grupach otrzymujących dodatek oleju rzepakowego do dawki. Dodatek $10 \%$ oleju rzepakowego do paszy spowodował statystycznie istotny $(\mathrm{P}<0,01)$ wzrost poziomu $\mathrm{pH}$ w żwaczu.

Dodatek tłuszczu roślinnego, w ilości $10 \%$, do dawek dla owiec nie spowodował istotnych zmian w procesach fermentacji żwacza. 